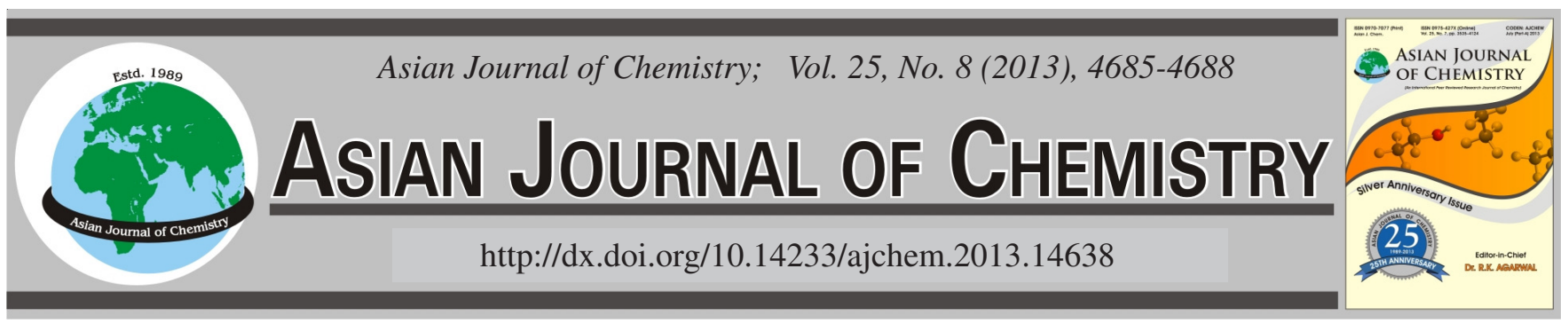

\title{
Cloud Point Extraction for Assessment of Lead and Cadmium Levels of Somatic Cells in Raw Milk Using Graphite Furnace Atomic Absorption Spectrometry
}

\author{
M.H. GivianRaD ${ }^{1, *}$, H. EzZATPanah ${ }^{2}$ and M. Chitsazi ${ }^{1}$
}

${ }^{1}$ Department of Chemistry, Science and Research Branch, Islamic Azad University, Tehran, Iran

${ }^{2}$ Department of Food Science and Technology, Science and Research Branch, Islamic Azad University, Tehran, Iran

*Corresponding author: Fax: +98 21 44868445; Tel: +98 21 44868449; E-mail: givianradh@yahoo.com

(Received: 29 September 2012;

Accepted: 20 February 2013)

AJC-13044

\begin{abstract}
The main objective of present study is to assess the probable associations between somatic cell (SC) levels and concentration of lead and cadmium in raw milk. Milk samples were collected from individual quarters of 30 Holstein cows and divided into three groups based on somatic cell level, including: low somatic cell level $(<200,000)$, intermediate somatic cell level $(200,000-800,000)$ and high somatic cell level $\left(>800,000\right.$ cell $\left.\mathrm{mL}^{-1}\right)$. A ligandless cloud point extraction (CPE) procedure has been developed for determination of $\mathrm{Pb}$ and $\mathrm{Cd}$ in microwave-assisted digested milk by using graphite furnace atomic absorption spectrometry (GFAAS). The analytes are quantitatively extracted to the phase rich in the non-ionic surfactant Triton X-100 after centrifugation. The surfactant rich-phase was dissolved with 0.5 $\mathrm{mL} 1.0 \mathrm{~mol} \mathrm{~L}^{-1} \mathrm{HNO}_{3}$ in methanol to decrease the viscosity. The optimal extraction and reaction conditions (e.g., surfactant concentration, $\mathrm{pH}$ and effect of time) were obtained. The detection limits of proposed method were calculated 28 and $2.36 \mathrm{ng} \mathrm{\textrm {L } ^ { - 1 }}$ for $\mathrm{Pb}$ and $\mathrm{Cd}$, respectively.
\end{abstract}

Key Words: Cadmium, Cloud point extraction, Lead, Raw milk, Triton X-100.

\section{INTRODUCTION}

The presence of milk in the diet occurs, mainly because this product contains protein and minerals essential to promoting the growth and maintenance of human life ${ }^{1}$. Nutritional value of dairy product depends on genetics, feeding system, housing and milking conditions and health of cows ${ }^{2}$. Mastitisinflammation of the mammary gland is a common disease in lactating cows $^{3}$. Subclinical infections are those which no visible changes occur in the appearance of milk or the udder, but milk production decreases, somatic cell count increases and the milk composition is altered ${ }^{4}$. Regarding subclinical mastitis, the problem is detection; the solution is some type of somatic cell counting when the somatic cells are counted. Subclinical mastitis is visualized and the milk production loss can be estimated. So, somatic cell count (SCC) in milk is a well known indicator reflecting mammary health and milk quality ${ }^{5}$.

Three main consequences of mastitis are increasing of permeability between blood and milk in secretory cells, decreasing of synthesizability of mammary gland and raising the sodium and chloride in milk ${ }^{2}$.

It seems that due to decrease of permeability of bloodmilk barrier and changes in ionic environment of milk, the concentration of heavy metal in milk may change, which could affect on contamination of milk and milk product.
Due to growing environmental pollution, monitoring the levels of toxic metals in milk is also necessary, because they can significantly influence the human life ${ }^{6}$. Two ubiquitous harmful metals are lead and cadmium. The content of these elements in milk and dairy product is usually very low, except when animals have consumed contaminated food and environment ${ }^{7}$. Determination of trace elements in milk and biological samples requires a very sensitive instrumental techniques and frequently pre-concentration step, because of their complex emulsion like matrices and low concentration ${ }^{8}$. Graphite furnace atomic absorption spectrometry (GFAAS) and inductively coupled plasma mass spectrometry (ICP-MS) are the most sensitive techniques for determination of a large number of elements and their power of detection extend to the low picogram range ${ }^{9}$. The cloud point extraction has been used in the separation science for extraction, purification and preconcentration. It is based on the behaviour of non-ionic surfactants in aqueous solution, which exhibit phase separation by an increase in temperature or by addition of salting-out agent ${ }^{10}$. Cloud point extraction was applied two different methods for separation of metal ions. In first method, metal ions are occurring complex with suitable ligand. Other method is based on direct application of cloud point extraction procedure without any ligand ${ }^{11}$. 
Most proposed procedures involve a step of digestion to eliminate the organic matrixes, the acid digestion induced by microwave energy is a well-established method ${ }^{8,12}$.

Although previous literature have reported the effect of clinical and sub-clinical mastitis on raw milk quality, no published data is available regarding to the probable association between lead and cadmium and somatic cell levels in sub-clinically mastitic milk. Therefore the aim of this study is to determine probable relationship between somatic cell levels and lead and cadmium content. This work described the application of ligandless cloud point extraction to determine $\mathrm{Pb}$ and $\mathrm{Cd}$ in milk sample by GFAAS using Triton X-100 as nonionic surfactant.

\section{EXPERIMENTAL}

All the reagents used were of the high purity available and at least of analytical reagent grade. Water was deionized in a Milli-Q system. The standard stock solution of $\mathrm{Cd}^{2+}$ and $\mathrm{Pb}^{2+}\left(1000 \mathrm{mg} \mathrm{L}^{-1}\right)$ was prepared by dissolving proper amount of $\mathrm{Cd}\left(\mathrm{NO}_{3}\right)_{2}$ and $\mathrm{Pb}\left(\mathrm{NO}_{3}\right)_{2}$ (Merck) in $2 \%$ nitric acid solution. Nitric acid $65 \%$ (Merck) and hydrogen peroxide $35 \%$ (Merck) was used for digestion. Triton X-100 stock solution (10\%, $\mathrm{v} / \mathrm{v}$ ) was prepared by dissolving $2 \mathrm{~mL}$ of concentrated solution (Merck) in hot deionized water. Sodium chloride at $10 \%$ $(\mathrm{w} / \mathrm{v})$ was used to promote phase separation. All the plastic and glassware equipments were cleaned by soaking in dilute $\mathrm{HNO}_{3}(1+9)$ and were rinsed with deionized water prior to use. Phosphate buffers $\left(0.1 \mathrm{~mol} \mathrm{~L}^{-1}\right)$ were used in the experiment for $\mathrm{pH}$ (7-8).

Varian Spectra AA-20 with a GTA-100 graphite tube atomizer was used throughout this study. Deuterium-arc background correction was employed to correct for nonspecific absorption. Hollow cathode lamps for $\mathrm{Cd}$ and $\mathrm{Pb}$ (Perkin-Elmer) were operated at 4 and $10 \mathrm{~mA}$, respectively, with a spectral bandwidth of $0.5 \mathrm{~nm}$. The analytical wavelength for $\mathrm{Cd} 228.8 \mathrm{~nm}$ and $283.3 \mathrm{~nm}$ for $\mathrm{Pb}$ were used as recommended by manufacturers. The sample injection volume was $20 \mu \mathrm{L}$. The graphite furnace temperature program is shown in Table- 1 for lead and cadmium. The acid digestion were performed using Milestone Ethos microwave oven, The conventional heating program used for digesting milk samples is described in Table-2. A KOKSUN centrifuge model H-11 was used to accelerate the phase-separation process. A 744 Metrohm pH meter was used for $\mathrm{pH}$ measurements.

Milk sampling: Milk samples were collected from morning milking of a commercial dairy farm located in a Tehran province.

\begin{tabular}{lcccc}
\multicolumn{5}{c}{ TABLE-1 } \\
\multicolumn{5}{c}{$\begin{array}{l}\text { GRAPHITE FURNACE TEMPERATURE PROGRAM } \\
\text { FOR LAED AND CADMIUM DETERMINATION }\end{array}$} \\
\hline \multicolumn{1}{c}{ Step } & Step & Temp. $\left({ }^{\circ} \mathrm{C}\right)$ & Time $(\mathrm{s})$ & $\begin{array}{c}\text { Argon flow rate } \\
\left(\mathrm{L} \mathrm{min} \text { }^{-1}\right)\end{array}$ \\
\hline Drying & 1 & 85 & 5.0 & 0.3 \\
Drying & 2 & 95 & 40.0 & 0.3 \\
Drying & 3 & 120 & 10.0 & 0.3 \\
Ashing & 4 & 500 & 5.0 & 0.3 \\
Ashing & 5 & 650 & 1.4 & 0.3 \\
Gas stop & 6 & 650 & 2.0 & 0.0 \\
Atomization & 7 & 2100 & 1.0 & 0.0 \\
Atomization & 8 & 2100 & 2.0 & 0.0 \\
Cleaning & 9 & 2300 & 2.0 & 0.3 \\
\hline
\end{tabular}

\begin{tabular}{cccc}
\multicolumn{4}{c}{ TABLE-2 } \\
& \multicolumn{3}{c}{ HEATING PROGRAM FOR MICROWAVE OVEN } \\
\hline Step & Temp. $\left({ }^{\circ} \mathrm{C}\right)$ & Ramp time $(\mathrm{min})$ & Hold time $(\mathrm{min})$ \\
\hline 1 & 110 & 3 & 0 \\
2 & 180 & 5 & 15 \\
\hline
\end{tabular}

Milk sampling was done from every quarters based on ISO $707^{13}$ and AOAC $968.12^{14}$. Therefore 30 pure Holestein lactating cows were selected which were in same age, lactating period, number of calving and diet, without antibiotic injection one week before sampling. Then samples were transferred to Iran Animal Breeding Center Laboratory located in Karaj rapidly at $4 \pm 1{ }^{\circ} \mathrm{C}$ for determining somatic cell count by fossomatic cell counter (Foss-5000). Therefore, milking cows were classified in three groups: low $(<200,000)$, intermediate $(200,000-$ $800,000)$ and high somatic cell count level (> 800,000 cells $\left.\mathrm{mL}^{-1}\right)$.

Mix sample was performed from mixing same volume of three levels ( $1 / 3$ low $+1 / 3$ intermediate $+1 / 3$ high $)$ and another sample was collected from bulk tank.

Sample preparation: A volume of $2.5 \mathrm{~mL}$ of milk was introduced into a vessel, then $10 \mathrm{~mL}$ of concentrated $\mathrm{HNO}_{3}$ and $7 \mathrm{~mL}$ of $\mathrm{H}_{2} \mathrm{O}_{2} 35 \%$ were added. After digesting, solutions were transferred to volumetric flasks and diluted to $50.0 \mathrm{~mL}$ with deionized water, this solutions was neutralized with 0.1 mol L-1 $\mathrm{NaOH}$.

General procedure: For cloud point extraction, $10 \mathrm{~mL}$ of digestion solution was transferred to a $15 \mathrm{~mL}$ centrifuge tube with a graduation line. After adding Triton X-100 $0.2 \%$ $(\mathrm{v} / \mathrm{v})$ and phosphate buffer $(0.1 \mathrm{M})$, the samples were shaken and left to stand in a thermostated water bath for $15 \mathrm{~min}$ at $60{ }^{\circ} \mathrm{C}$ before centrifugation and were not heated, when $\mathrm{NaCl}$ was used for inducing the cloud point. Separation of the phases was achieved by centrifugation at $3500 \mathrm{rpm}$ for $15 \mathrm{~min}$. The mixture was cooled in ice bath to increase the viscosity of the surfactant-rich phase and the aqueous phase was easily decanted by simply inverting the tube. The remaining micellar phase was dissolved in $0.5 \mathrm{~mL}$ of $1.0 \mathrm{~mol} \mathrm{~L}^{-1} \mathrm{HNO}_{3}$ in methanol and then the analyte contents were determined by GFAAS against a blank solution. Blank solution was submitted to the same procedure and measured in parallel to the samples.

\section{RESULTS AND DISCUSSION}

Effect of experimental conditions: To take full advantage of the procedure, the reagent concentrations and reaction conditions must be optimized. Any parameter ( $\mathrm{pH}$, surfactant concentration, incubation temperature, etc.) affecting the proposed reaction and micelle formation was investigated in order to find the optimum experimental condition.

Effect of $\mathbf{p H}$ : The $\mathrm{pH}$ was the first parameter examined for its effect on the extraction of lead and cadmium. Optimum $\mathrm{pH}$ for proposed extraction system was preferred to 8 .

Effect of Triton X-100 concentration: A successful cloud point extraction should maximize the extraction efficiency by minimizing the phase: volume ratio $\left(\mathrm{V}_{\text {org }} / \mathrm{V}_{\text {aqueous }}\right)$, thus improving its concentrating ability. Triton X-100 was chosen for the formation of the surfactant rich phase due to its low cloud point temperature and high density of the surfactant rich phase, 
which facilitates phase separation by centrifugation. The concentration of surfactant that is used in the cloud point extraction is a critical factor. Thus, concentration of Triton $\mathrm{X}$ 100 was investigated between $0.05-0.4 \%$ (v/v) for extraction performance. The maximum absorbance values of $\mathrm{Pb}$ and $\mathrm{Cd}$ in $0.2 \%(\mathrm{v} / \mathrm{v})$ Triton X-100 was found, therefore $0.2 \%$ (v/v) Triton X-100 was selected for subsequent work.

Effect of temperature: The effect of equilibration temperature and incubation time was investigated. It is desirable to employ the shortest incubation time and the lowest possible equilibration temperature, which compromise efficient separation of the phases. The results showed that at constant incubation time of 15 min equilibration temperature of $60{ }^{\circ} \mathrm{C}$ is sufficient for maximum recovery of the lead and cadmium.

Effect of $\mathrm{NaCl}$ concentration: Studies on the effects of some additives, such as anionic and non-ionic surfactants and electrolytes, as $\mathrm{NaCl}, \mathrm{KNO}_{3}$ and $\mathrm{MgCl}_{2}$, on the cloud point behaviour of non-ionic surfactants have been reported ${ }^{15}$. It was observed that the presence of electrolytes decreases the cloud point (salting-out effect), resulting in a more efficient extraction. The lower cloud point is attributed to electrolytes promoting dehydration of the poly (oxyethylene) chains ${ }^{16}$. According to Hiller et al. ${ }^{17}$ the salting-out phenomenon is directly related to desorption of ions to the hydrophilic parts of the micelles, increasing inter-attraction between micelles and consequently leading to the precipitation of surfactant molecules.

Base on this discussion, $\mathrm{NaCl}$ was investigated as electrolyte in the concentration range from 0.5 to $5 \%(\mathrm{w} / \mathrm{v})$ with the goal of obtaining the cloud point without heating. It was observed that the highest absorbance at $1 \%(\mathrm{w} / \mathrm{v}) \mathrm{NaCl}$ concentration. Therefore, $1 \%(\mathrm{w} / \mathrm{v}) \mathrm{NaCl}$ concentration was used in all further experiments.

Effect of added methanol volume: The surfactant-rich phase obtained after cloud point preconcentration contains a high concentration of Triton X-100 and at the same time, the volume obtained is rather small $(20 \mu \mathrm{L})$, methanol containing $0.1 \mathrm{~mol} \mathrm{~L}^{-1} \mathrm{HNO}_{3}$ was added to the surfactant-rich phase after phase separation. Moreover, it was necessary to decrease the viscosity of the rich phase without excessive dilution of the micelle to facilitate the introduction of the sample into the atomizer of the spectrometer. Therefore, $0.5 \mathrm{~mL}$ of diluent was chosen as the optimized value and added to the surfactantrich phase.

Lead and cadmium contents of milk: By increasing somatic cell levels, the amounts of lead and cadmium in milk were increased; the results were shown in Fig. 1 for lead and cadmium. The significant differences were observed in lead and cadmium content in all three somatic cell levels $(\alpha=0.05)$. Also according to linear regression diagram, which showed in Fig. 2 for lead and Fig. 3 for cadmium, ca. $96.5 \%\left(\mathrm{R}^{2}=\right.$ 0.965 ) of the changes in lead content of milk samples and 97 $\%$ of the $\left(\mathrm{R}^{2}=0.97\right)$ changes in cadmium content can be attributed to increasing the somatic cell levels.

Inflammation of mammary gland leads to a variety of compositional changes in milk either because of local effects or because of serum components entering the milk and the movement of some normal milk components out of the alveolar lumen into the perivascular space ${ }^{18}$. Also, intramammary infection results in damage to the ductal and secretory epithelium,

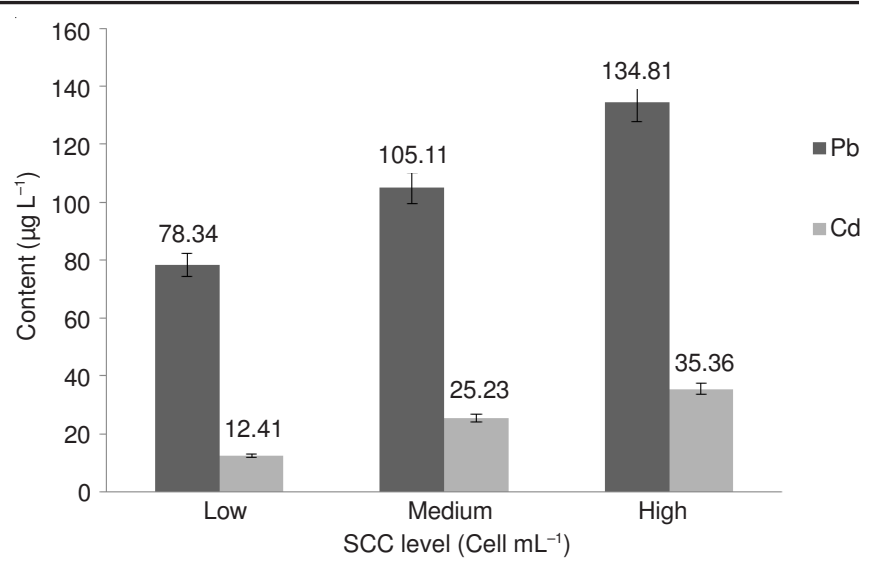

Fig. 1. Concentration of lead and cadmium with somatic cell levels acid

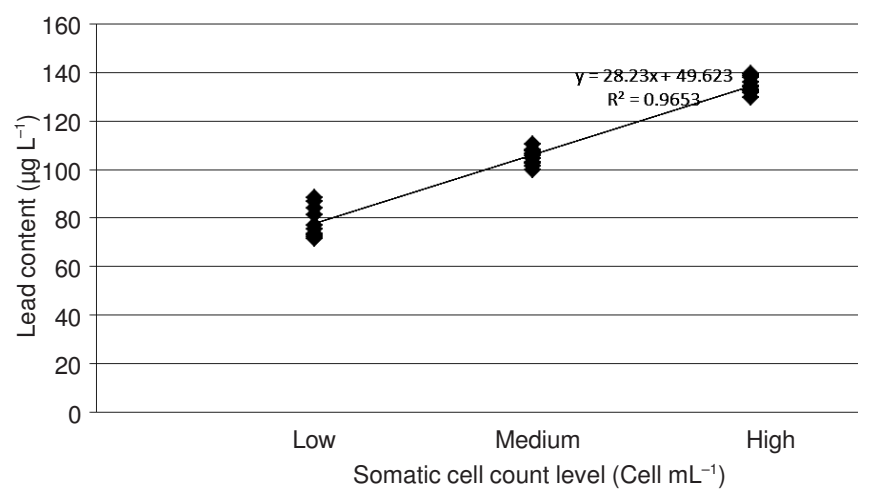

Fig. 2. Linear regression of somatic cell level effect on lead concentration of milk

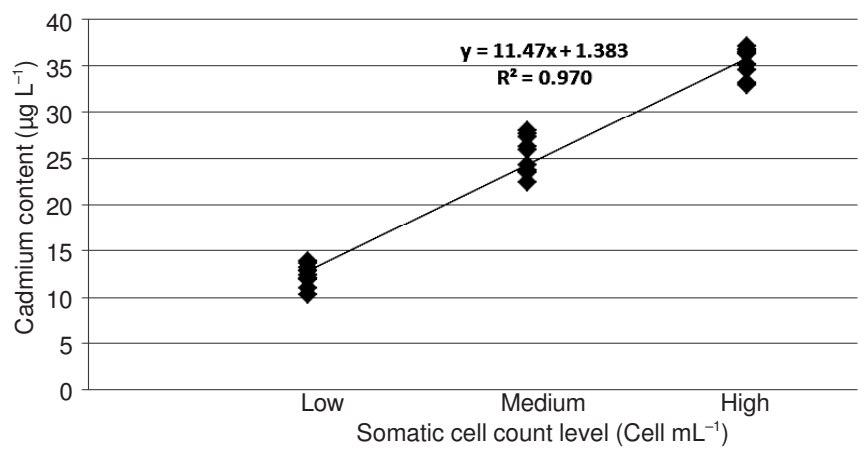

Fig. 3. Linear regression of somatic cell level effect on cadmium concentration of milk samples

an opening of the "tight junction" between secretory cells and the increasing of permeability of the blood capillaries. Thus, sodium and chloride (which are high in extracellular fluid) pour into the lumen of the alveolus and, in order to maintain osmolarity, potassium levels decrease proportionately. The levels of calcium and phosphorous is also affected by mastitis ${ }^{19}$. Increase of permeability of the blood-milk barrier in infected quarters and abnormal transference of some compounds from blood into milk due to mastitis can be concerned as the most important reasons for increasing of lead and cadmium contents in milk.

Our finding showed that, the contents of lead and cadmium were higher in bulk tank than the contents in low somatic cell level. So, this made by mixing high somatic cell level milk with normal milk and increasing the contamination of bulk tank milk. 
Comparing our results with the accepted upper limits, mean value of lead was below the general statutory limit of 1 $\mathrm{mg} \mathrm{kg}^{-1}$ set by the lead in food regulations ${ }^{20}$. Conversely, the amount of lead was above the proposed European maximum limit ${ }^{21}$ of $20 \mu \mathrm{g} \mathrm{kg}^{-1}$. Provisional tolerable weekly intake of $\mathrm{Pb}$ and $\mathrm{Cd}$ are 25 and $7 \mu \mathrm{g} \mathrm{kg}^{-1}$ body weight for all human groups, respectively ${ }^{22}$.

Base on the present finding, levels of metals under study were higher than levels recorded by Tajkarimi et al. ${ }^{23}$ as 7.9 $\mathrm{ng} \mathrm{L^{-1 }}$ for lead and $7.1 \mathrm{ng} \mathrm{L}^{-1}$ for cadmium. High levels of heavy metal in this study may be attributed to the high contamination of animal feed and water by such pollutants and could be excreted into milk at various levels. In this respect, several studies have been carried out to assess metal content of milk from different areas ${ }^{24}$. They reported that $\mathrm{Pb}$ and $\mathrm{Cd}$ were detected in cow's milk samples at levels ranged between 1.703.35 and $0.07-0.01 \mu \mathrm{g} \mathrm{L}^{-1}$, respectively. However, other author determined $\mathrm{Pb}$ and $\mathrm{Cd}$ 0.03-0.18 and 0.004-0.009 $\mathrm{mg} \mathrm{L}^{-1}$. Regarding to the investigation of Lante et $a l^{25}$, they reported that $\mathrm{Pb}\left(5.23 \mu \mathrm{g} \mathrm{L}{ }^{-1}\right)$ and $\mathrm{Cd}(0.4 \mu \mathrm{g} / \mathrm{L})$ were detected at various levels. On the other hand, Caggiano et al. ${ }^{26}$ reported that, $\mathrm{Pb}$ and $\mathrm{Cd}$ were detected at mean levels of 0.20 and $0.06 \mathrm{mg} \mathrm{kg}^{-1}$ cow's milk, respectively.

Correlation analysis was carried out based on Pearson coefficient. Positive correlations between two data mean that those two data increase or decrease together. Accordingly by increasing the somatic cell level, the concentrations of lead and cadmium in milk increase, as well (Table-3).

TABLE-3

PEARSON CORRELATION MATRIX FOR EVALUATION OF TEST DATA CORRELATION IN THREE OF SC LEVELS

\begin{tabular}{lcccccc}
\hline & $\mathrm{Cd}$ & $\mathrm{Cd}$ & $\mathrm{Cd}$ & $\mathrm{Pb}$ & $\mathrm{Pb}$ & $\mathrm{Pb}$ \\
& Low & Medium & High & Low & Medium & High \\
\hline Cd Low & 1 & $\underline{0.693}$ & $\mathbf{0 . 7 6 6}$ & $\underline{0.651}$ & $\mathbf{0 . 7 7 2}$ & $\underline{0.802}$ \\
Cd Medium & & 1 & $\underline{0.712}$ & $\mathbf{0 . 7 6 7}$ & $\mathbf{0 . 7 7 4}$ & $\mathbf{0 . 7 6 9}$ \\
Cd High & & & 1 & $\mathbf{0 . 8 1 0}$ & $\mathbf{0 . 7 7 3}$ & $\mathbf{0 . 7 4 9}$ \\
Pb Low & & & & 1 & $\underline{0.652}$ & $\underline{0.698}$ \\
Pb Medium & & & & & 1 & $\underline{0.716}$ \\
Pb High & & & & & & 1 \\
\hline
\end{tabular}

Note: In this table bold number show a significant correlation with 95 $\%$ confidence $(r=0.05)$ and underline numbers refer to a significant correlation with $99 \%$ confidence $(r=0.01)$.

Analytical figures of merit: The limit of detection, defined as $C_{L}=3 S_{B} / m$, where $C_{L}, S_{B}$ and $m$ are the limit of detection, standard deviation of blank and the slope of the calibration graph, respectively, were $2.36 \mathrm{ng} \mathrm{L}^{-1}$ for cadmium and $28 \mathrm{ng} \mathrm{L}^{-1}$ for lead. RSD \% for lead and cadmium were 4 and 2.8 , respectively. The enrichment factor, $\mathrm{f}_{\mathrm{c}}$, defined as the ratios of the cadmium or lead concentration in the surfactant-rich phase to that in the bulk phase initially, will remain constant in the same surfactant solutions, regardless of the initial concentration.

$$
\mathrm{f}_{\mathrm{c}}=\mathrm{C}_{\mathrm{S}} / \mathrm{C}_{\mathrm{O}}
$$

where $\mathrm{C}_{\mathrm{S}}$ is cadmium or lead concentration in the surfactantrich phase after phase separation and $\mathrm{C}_{\mathrm{O}}$ is the initial concentration of these elements. The enrichment factor was found ${ }^{20}$.

\section{Conclusion}

As observed before, by increasing the somatic cell levels lead and cadmium contents of milk were increased. This effect was observed even in sub-clinical mastitis, which disease symptoms and milk abnormalities are not visible. In a farm for every case of clinical mastitis, there are 20-40 times as many cases of sub-clinical mastitis; so if we count the increase of lead and cadmium concentration of milk in sub-clinical cases, the important of matter will be appeared. If subclinical mastitis is monitored and milk is ranked in the first stages of production, a lot of nutritional problems may be solved. Therefore, dairy industry should notice to somatic cell count factor more. Moreover, milk should be monitored and ranked in quarter levels in farm. Consequently, production of high quality dairy products with considerable nutritional value cannot be expected without milk ranking in farm level and mastitis preventing and controlling.

\section{ACKNOWLEDGEMENTS}

The authors are grateful to the Laboratory Complex of Islamic Azad University for valuable technical assistance.

\section{REFERENCES}

1. V.A. Soares, M.M.M. Kus, A.L.C. Peixoto, J.S. Carrocci, R.F.S. Salazar and H.J. Izário Filho, Food Control, 21, 45 (2010)

2. C. Yalcin, Y. Cevger, K. Turkyilmaz and G. Uysal, Turk. J. Vet. Anim. Sci., 24, 599 (2000).

3. W.N. Philpot and S.C. Nickerson, Mastitis - What is it? Babson Bros. Co., Publishing, Napervile, IL, pp. 1-7 (1991).

4. J.V. Tyler and J.S. Cullor, in ed.: B.P. Smith, Mammary Gland Health and Disorders, Large Animal Internal Medicine, London, Mosby, edn 3, pp. 1019-1022 (1990).

5. J.A. Smith, J. Leukocyte Biol., 56, 672 (1994).

6. F. Licata, D. Martino, M. Calo and F. Naccari, Environ. Int., 30, 1 (2004).

7. M. Blanusa, J. Hrsak and M. Fugas, Enviromental Contamination, CEP Consultants Ltd., Edinburgh, Vol. 2, p. 490 (1990).

8. H. Karimi, M. Ghaedi, A. Shokrollahi, H.R. Rajabi, M. Soylak and B. Karami, J. Hazard. Mater., 151, 26 (2008).

9. M. Sperling, X. Yin and B. Welz, J. Anal. Atom. Spectrom., 6, 295 (1991).

10. F.H. Quina and W.L. Hinze, Ind. Eng. Chem. Res., 38, 4150 (1999).

11. S. Candir, I. Narin and M. Soylak, Talanta, 77, 289 (2008).

12. M. Tuzen and M. Soylak, Food Chem., 102, 1089 (2007).

13. Anon, Milk Products-Guidance of Sampling, International Standards Organization, Geneva, ISO 707 (1997).

14. Anon Official Methods of Analysis of the AOAC, Arlington, USA: Association of Official Analytical Chemists, edn. 15 (2002).

15. C.C. Nascentes and M.A.Z. Arruda, Talanta, 61, 759 (2003).

16. J.K. Armstrong, B.Z. Chowdhry, M.J. Snowden and S.A. Leharne, Langmuir, 14, 2004 (1998).

17. G. Komaromy-Hiller, N. Calkins and R. Wandruszka, Langmuir, 12, 916 (1996)

18. R.J. Harmon, J. Dairy Sci., 77, 2103 (1994).

19. J.B. Coulon, P. Gasqui, J. Barnouin, A. Ollier, P. Pradel and D. Pomies, Anim. Res., 51, 383 (2002).

20. The Lead in Food Regulations, 1979. (S.I. [1979] No. 1254) as amended by The Lead in Food (Amendment) Regulations 1985 (S.I. [1985]).

21. European Commission, Draft Commission Regulation Setting Maximum Limits for Certain Contaminants in Foodstuffs. December, 111/5125/ 95/REV. 3 (1997).

22. Codex Alimentarius Commission, Codex General Standard for Contaminants and Toxin in Foods, Codex Stan. 1993 (2007).

23. M. Tajkarimi, M. Ahmadi Fagih, H. Poursoltani, V.N. Sastry, A. Salah Nejad, A.A. Motallebi and H. Mahdavi, J. Food Chem., 19, 495 (2008).

24. A.A.K. Abou-Arab, J. Food Chem., 59, 115 (1997).

25. A. Lante, G. Lomolino, M. Cagnin and P. Spettoli, J. Food Control, 17, 229 (2004).

26. R. Caggiano, S. Sabia, M. D'Emilio, A. Anastasio and M. Ragosta, Environ. Res., 99, 48 (2005). 